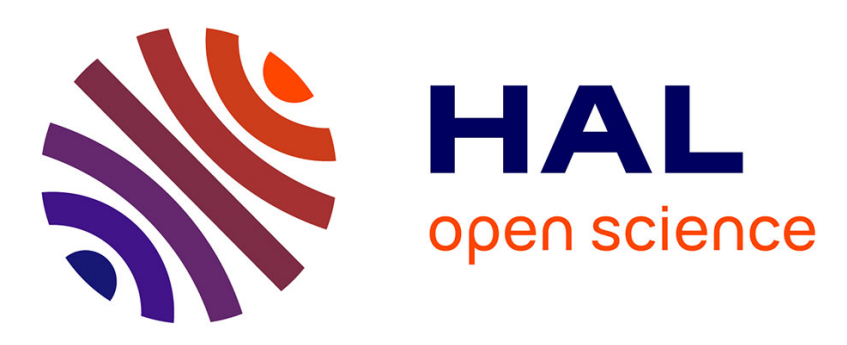

\title{
Effect of tissue parameters on skin heating due to millimeter EM waves
}

Lucas Zilberti, Damien Voyer, Oriano Bottauscio, Mario Chiampi, Riccardo Scorretti

\section{- To cite this version:}

Lucas Zilberti, Damien Voyer, Oriano Bottauscio, Mario Chiampi, Riccardo Scorretti. Effect of tissue parameters on skin heating due to millimeter EM waves. IEEE CEFC, May 2014, Annecy, France. pp.CD ( 365 / PE3: 12). hal-01132167

\section{HAL Id: hal-01132167 \\ https://hal.science/hal-01132167}

Submitted on 16 Mar 2015

HAL is a multi-disciplinary open access archive for the deposit and dissemination of scientific research documents, whether they are published or not. The documents may come from teaching and research institutions in France or abroad, or from public or private research centers.
L'archive ouverte pluridisciplinaire HAL, est destinée au dépôt et à la diffusion de documents scientifiques de niveau recherche, publiés ou non, émanant des établissements d'enseignement et de recherche français ou étrangers, des laboratoires publics ou privés. 


\title{
Effect of tissue parameters on skin heating due to millimeter EM waves
}

\author{
Luca Zilberti ${ }^{1}$, Damien Voyer $^{3}$, Oriano Bottauscio ${ }^{1}$, Mario Chiampi ${ }^{2}$, Riccardo Scorretti ${ }^{3}$ \\ ${ }^{1}$ Istituto Nazionale di Ricerca Metrologica, Strada delle Cacce 91, 10135 Torino, Italy \\ ${ }^{2}$ Politecnico di Torino, C.so Duca degli Abruzzi 24, 10129 Torino, Italy \\ ${ }^{3}$ Université de Lyon - Ampère (CNRS UMR5005, École Centrale de Lyon, INSA-Lyon, UCBL), F-69134 Écully Cedex, France \\ 1.zilberti@inrim.it
}

\begin{abstract}
This paper investigates the influence of electrical and thermal human tissue parameters on the heating of a body illuminated by a millimiter plane electromagnetic wave. A stochastic approach is considered with a three-layer model of the body: it is found that the parameters of skin play a major role.

Index Terms-dosimetry, millimeter wave propagation.
\end{abstract}

\section{INTRODUCTION}

The increasing application of millimeter electromagnetic (EM) waves makes important the investigation of their effects on human health, in particular the related heating of tissues. In the present work, we use a 1D model, previously developed under steady-state conditions [1], to evaluate the heating of tissues when exposed for a limited time to a $100 \mathrm{GHz}$ linearly polarized plane wave, carrying a unitary power density and normally incident to the body surface. The human body is modeled as a stratified structure with 3 layers: skin, subcutaneous adipose tissue (SAT) and muscle. Due to the large variability in electrical and thermal characteristics found in the literature for each of these layers, the main purpose of the paper is to investigate the influence of tissue parameters in the thermal response of the body. Helmholtz's electromagnetic equations are solved analytically [1], to compute the volume power density $P_{e m}$ transferred by the field to the tissues. Then, $P_{e m}$ becomes the source term for the bioheat equation [2], which is solved by Finite Elements in the time domain through a Crank-Nicolson procedure. An exposure of $1 \mathrm{~s}$ followed by a "cooling period" of $100 \mathrm{~s}$ is simulated and the maximum temperature elevation $\theta_{\max }$ is analyzed.

\section{RESULTS OF VARIABILITY}

The input parameters reported in Table I are taken into account in a stochastic approach [3]: the permittivity $\varepsilon_{\mathrm{r}}$, the electrical conductivity $\sigma$, the thermal conductivity $\lambda$, the perfusion coefficient $h_{\mathrm{b}}$ and the specific heat capacity $\rho \mathrm{c}_{\mathrm{s}}$ are varied according to the variability found in literature. It is assumed that all the parameters are independent and follow a uniform distribution. The stochastic method is based on a

TABLE I

RANGE OF VARIATION FOR THE PARAMETERS OF THE MODEL

\begin{tabular}{|c|c|c|c|}
\hline & Skin & SAT & Muscle \\
\hline$\varepsilon_{\mathrm{r}}$ & $2.8-8.4$ & 3.67 & 8.63 \\
\hline$\sigma\left(\mathrm{Sm}^{-1}\right)$ & $19.7-59.1$ & 10.6 & 62.5 \\
\hline$\lambda\left(\mathrm{Wm}^{-1}{ }^{\circ} \mathrm{C}^{-1}\right)$ & $0.32-0.50$ & $0.16-0.50$ & $0.32-0.56$ \\
\hline $\mathrm{h}_{\mathrm{b}}\left(\mathrm{kWm}^{-3} \mathrm{C}^{-1}\right)$ & $3.34-12.3$ & $1.15-4.75$ & $1.31-6.49$ \\
\hline$\rho_{\mathrm{s}}\left(\mathrm{MJm}^{-3} \mathrm{C}^{-1}\right)$ & $3.46-4.12$ & $1.47-3.08$ & $2.73-4.48$ \\
\hline Thickness $(\mathrm{mm})$ & $1-4$ & $1.5-10$ & $\infty$ \\
\hline
\end{tabular}

polynomial chaos expansion of $\theta_{\max }$ and requires simulations of the numerical model above described for judicious values of the input parameters. Using polynomials of order 3 , the algorithm converges with 439 simulations. Figure 1 gives the probability density function computed from the polynomial chaos expansion. The stochastic method also gives the partial variance and the total effect [4] of the different input parameters (Table II - no significant effect is found for missing parameters). The skin seems to be the most influential tissue, as expected since the millimeter EM wave does not significantly penetrate the other tissues. Moreover, the electrical parameters $\left(\varepsilon_{\mathrm{r}}\right.$ and $\left.\sigma\right)$ are uncoupled from the thermal ones $\left(\lambda\right.$ and $\left.\rho c_{s}\right)$ since the total effect and the partial variance are the same for thermal parameters: this result is more surprising because $P_{e m}$, the source term for the thermal equation, depends on electrical parameters.

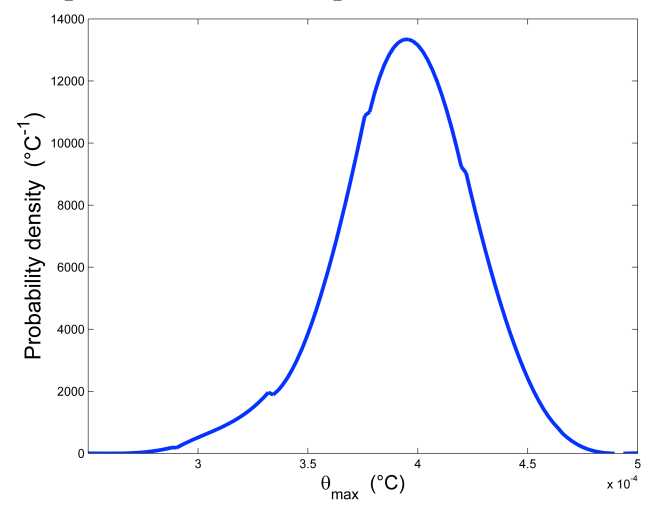

Fig 1: probability density function of $\theta_{\max }$ (cf. Table I)

TABLE II

SENSITIVITY ANALYSIS

\begin{tabular}{|c|c|c|}
\hline Parameter & Partial Variance $(\%)$ & Total effect $(\%)$ \\
\hline$\varepsilon_{\mathrm{r}}$ skin & 28.2 & 36.2 \\
\hline$\sigma$ skin & 20.8 & 29.1 \\
\hline$\lambda$ skin & 23.3 & 23.9 \\
\hline$\rho c_{\mathrm{s}}$ skin & 18.9 & 19.0 \\
\hline Thickness skin & 0.3 & 0.4 \\
\hline
\end{tabular}

\section{REFERENCES}

[1] Zilberti, L., et al. A model to analyze the skin heating produced by millimeter and submillimeter electromagnetic waves, IEEE Int. Conf. on. Electromagnetics in Advanced Applications (ICEAA), Torino, 2013.

[2] H. Pennes, Analysis of tissue and arterial blood temperatures in the resting human forearm, J. Appl. Physiol., Vol. 1, 1948.

[3] D. Voyer et al. Probabilistic methods applied to $2 D$ electromagnetic numerical dosimetry, COMPEL, 27.3 (2008): 651-667.

[4] D. Voyer, et al. Comparison of methods for modeling uncertainties in a $2 D$ hyperthermia problem, PIER B Progress in Electromagnetic Research, Vol. 11, pp. 189-204, 2009. 